\title{
Siyah Alaca Sığırlarda Bazı Meme ve Vücut Ölçüleri ile Somatik Hücre Sayıları Arasındaki İlişkiler*
}

\author{
Sıraç YAVUZ ${ }^{1 * *}$, Ali KAYGISIZ ${ }^{1}$ \\ ${ }^{1}$ KSÜ, Ziraat Fakültesi, Zootekni Bölümü, Kahramanmaras
}

Geliş (Received): 21.07.2015

Kabul (Accepted): 05.08.2015

\begin{abstract}
ÖZET: Bu çalışmada, Kahramanmaraș Sütçü İmam Üniversitesi Ziraat Fakültesi bünyesindeki Hayvansal Üretim Uygulama ve Araştırma Merkezi (HAYMER)'nin uygulama ve geliştirme çiftliğinde yetiştirilen 29 baş Siyah-Alaca süt sığırların süt verimi, somatik hücre sayısı ile bazı meme ve vücut ölçüleri arasındaki ilişkiler incelenmiştir. Süt örnekleri ve somatik hücre sayısı ölçümleri Aralık 2012 ve Kasım 2013 tarihleri arasında ayda bir defa sabah ve akşam sağımında alınmıştır. Araştırmada, 305 günlük süt verimi genel ortalaması $3111 \pm 133.5 \mathrm{~kg}$, somatik hücre sayısı ortalaması $419.88 \pm 67.5 * 10^{3}$ adet $/ \mathrm{ml}$ ve logSHS değeri $2.44 \pm 0.69$ olarak bulunmuștur. Süt verimi ile somatik hücre sayısı arasındaki ilişki istatiksel olarak önemli bulunmamıştır $(\mathrm{P}>0.05)$. Kontrol aylarına göre ortalama $\operatorname{logSHS}$ değeri en düşük 2.425 \pm 0.138 (Mayıs) ve en yüksek logSHS değeri ise $2.557 \pm 0.142$ (Mart) olarak bulunmuştur. Meme özelliklerinden, ön meme başları çapı, arka meme başları arası mesafe ve arka meme başları uzunluğu ile somatik hücre sayısı arasında önemli ilişkiler tespit edilmiştir $(\mathrm{P}<0.05)$. Ayrıca, ön meme başları çapı ile süt verimi arasındaki ilişki de önemli bulunmuştur $(\mathrm{P}<0.05)$.
\end{abstract}

Anahtar Kelimeler: Siyah-Alaca, Süt verimi, Somatik hücre sayısı, Meme ölçüleri, Vücud ölçüleri, Korelasyon

\section{The Relationship Between Some Body and Udder Measurements with Somatic Cell Count in Holstein Cows}

ABSTRACT: In this research, the relationship among milk yield, somatic cell count and linear type traits were examined to the 29 head Holstein Friesian cows reared at the Kahramanmaraş Sütçü İmam University's Animal Progressing and Practicing Farm (HAYMER). The relationship among milk yield, somatic cell count and linear type traits were searched. Somatic cell counts were determined from collecting milk samples on December 2012 to November 2013 in morning or evening milking time once a month. In this study, average 305 days milk yield was determined as $3111 \pm 133.5 \mathrm{~kg}, 2.44 \pm 0.69 \mathrm{logsh}$ somatic cell count average was $419.88 \pm 67.5 * 10^{3}$ cell $/ \mathrm{ml}$ and the relationship among milk yield, logshs and somatic cell count wasn't found statistically significant. Logshs lowest average value of $2.425 \pm 0.138$ compared to the control month (May) and the highest logshs value of $0.142 \pm 2.557$ (March), respectively. From teat measurements, the relationships among somatic cell and front teats diameter, rear teats distance, rear teats length was detected significant $(\mathrm{P}<0.05)$. Also, the relationship between the diameter of the front teats in milk yield was significant $(\mathrm{P}<0.05)$.

Key Words: Milk yield, Somatic cell count, Body and teats measurements

\section{GİRIŞ}

Türkiye'de hayvan ıslahının kolaylaştırılması ve geliştirilmesi için veri toplama ve değerlendirilmesi en önemli konulardan biridir. Sığırlar verim kayıtlarının yanı sıra bazı sübjektif, dış yapı özellikleri ile de sınıflandırılmaktadır. Süt sığırı yetiştiricileri açısından arzu edilen bir sürü idaresini gerçekleştirmek için tip sınıflandırma önemli bir yöntemdir. Süt sığırlarında uzun ömürlülük ve hayvanlardan yüksek düzeyde verim alınması amacıyla, verim kayıtlarının yanı sıra dış görünüş özelliklerine de dikkat edilmektedir. Süt sığırlarında tip özellikleri, uzun ömürlülüğü ve dolaylı seleksiyon kriteri olarak da sürüde kalma süresini erken dönemde tahmin etmede kullanılmaktadır (Larroque ve Ducrocq, 2001).

Tip özellikleri, sürüdeki hayvanların uzun ömürlülüğü ile ilişkili olmasının yanı sıra SHS ile olan ilișkisi bakımından da önem arz etmektedir. Nitekim Rogers ve ark., (1991) SHS ve meme derinliği arasında yüksek genetik korelasyonun olduğunu, özellikle meme başı uzunluğu ve SHS arasında pozitif yönde bir ilişki olduğunu ve sonuç olarak da tip özelliklerine bakılarak mastitise dayanıklılık yönünde seleksiyon yapılabileceğini ifade etmişlerdir.

Çĭ̆ sütün kalite kriterlerinin ortaya konmasında somatik hücre sayısı en önemli belirleyici etkenlerden biridir. Meme dokusunda enfeksiyon oluştuğunda, sütte lökosit ve epitel hücre (somatik hücre) sayısında artış olduğu, çiğ sütlerde düşük sayıda bulunan Saha'nın normalin üzerine çıkmasının sığırın mastitisli olduğunun göstergesi olacağı, bu nedenle SHS'nın süt kalitesi ve mastitisi belirlemede önemli bir kriter olarak kullanılabileceği bildirilmiştir (Çoban ve ark., 2007; Yalçın ve ark., 2000 Aytekin ve Boztepe 2014).

Bu çalışmanın amacı Holstein ırkı sığırlarda SHS ile dış yapı arasındaki ilişkininin ortaya konulması amaçlanmıștır. 


\section{MATERYAL ve METOT \\ Materyal}

Hayvan materyali

Araştırmanın hayvan materyalini Kahramanmaraş Sütçü İmam Üniversitesi Ziraat Fakültesi bünyesindeki Hayvansal Üretim Uygulama ve Araştırma Merkezi (HAYMER) uygulama çiftliğinde yetiştirilen farklı yaşlarda 29 baş Siyah Alaca sığır oluşturmuştur.

Araştırmaya başlangıçta 29 baş sığır ile başlanmış olup, ilerleyen safhalarda bazı hayvanların kuruya alınması veya hastalıktan dolayı sağım yapılmadığından sığır sayısında değişiklikler olmuştur.

\section{Sürü İdaresi ve Barındırma}

İşletmede De Laval firmasına ait sağım sistemi mevcut olup, sabah ve akşam olmak üzere günde iki kez sağım yapılmıştır. Hayvanlara günde üç kez $7 \mathrm{~kg}$ yem verilmiştir.

\section{Metot}

\section{Süit Örneklerinin Alınması}

Araştırma süresince Aralık 2012 ve Kasım 2013 tarihleri arasında ayda bir defa sabah ve akşam sağımında her sığırdan yaklaşık olarak $100 \mathrm{ml}$ süt örneği elle sağım yöntemi ile alınmıştır. Bir yıl boyunca her bir sığırdan en az 10 kez örnek alınmıştır. Örneklerin hepsi analize tabii tutulmuştur.

\section{Somatik Hücre Sayısının Belirlenmesi}

Her ay düzenli olarak sı ğırlardan alınan çĭ̆ süt örneklerinde somatik hücre sayımları yapılmıştır. Süt örnekleri 200 ml'lik tüplerden sayım kitlerine çekilerek, DCC (De Laval Somatik Hücre Sayım Cihazı) cihazına konularak yapılmıştır.

\section{Günlük Süt Veriminin Hesaplanması}

HAYMER'inde süt sağım ünitesi otomatiktir. Sağım sistemi ve buna bağlı sürü yönetim programı bilgisayarlı ortamda mevcuttur. Günlük yapılan sağımlarda hayvan başına elde edilen süt miktarı bilgisayara aktarılarak kayıt altına alınmaktadır. Denetim günü verimlerinden 305 günlük süt veriminin hesaplanmasında ICAR'ın test aralıkları metodu (TIM) kullanılmıştır (ICAR, 2003).

Bu metot;

$\mathrm{X}=\left[\left(\mathrm{k}_{1} \cdot \mathrm{A}\right)+\left(\left(\mathrm{k}_{1}+\mathrm{k}_{2}\right) / 2\right) \mathrm{a} 1+\ldots \ldots+\left(\left(\mathrm{k}_{\mathrm{n}-1}+\mathrm{k}_{\mathrm{n}}\right) / 2\right)\right.$ $\left.a_{n}+\left(k_{n} C\right)\right]$

C: Son kontrol günü ile kuruya çıkma arasında kalan süre'yi (gün) ifade eder.

Formülde yer alan $\left(k_{n} C\right)$, son kontrol günü ile kuruya çıkma arasında geçen süredeki süt veriminin tespitini yapmaktadır.

$\mathrm{n}$ : Kontrol sayıs1

$\mathrm{k}$ : Kontrol verimlerinin toplamı

a: Kontrol aralığ 1

A: Doğum-ilk kontrol arasında geçen süre

$\mathrm{X}$ : Süt verimi

\section{Doğrusal Tip Özellikleri}

Meme ve vücut ölçülerinin hesaplanmasında Gökçe, (2011) ve Şahin, (2015)'nin bildirişlerinden yararlanılmıştır. İneklerden Sağrı Yüksekliği (SY), Göğüs Genişliği (GG), Beden Derinliği (BD), Boyun çevresi (BÇ), Sağrı Genişliği (SG), Ön Meme Başları Uzunluğu (ÖMBU), Meme Derinliği (MD), Arka Meme Derinliği (AMD), Arka Meme Başları Uzunluğu (AMBU), Ön Meme Başları Arası Mesafe (ÖMBAM), Arka Meme Başları Arası Mesafe (AMBAM), Yan Meme Başları Arası Mesafe (YMBAM), Ön Meme Başları Çapı (ÖMBÇ), Arka Meme Başları Çapı (AMBÇ), Ön Meme Başları Yerden Yüksekliği (ÖMBYY), Arka Meme Başları Yerden Yüksekliği (AMBYY) gibi özellikler saptanmıştır.

\section{İstatistiki Analizler}

305 günlük süt verimi ve somatik hücre sayısına etkili olduğu düşünülen dış yapı özelliklerinin etkilerini tespit etmek amacıyla Aşamalı Doğrusal Regresyon Analizi (Stepwise Linear Regression Analysis) yaklaşımından yararlanılmıştır.

SHS ve günlük süt verimine kontrol sirası ve buzağılama aylarının etkisi varyans analizi ile, SHS ile süt verimi arasındaki kantitatif ilişki kovaryans analizi ile araştırılmıştır. Kullanılan matematik modeller aşağıda verilmiştir.

Varyans analizi için kullanılan matematik model; $Y_{i j k}=\mu+a_{i}+b_{j}+e_{i j k}$

Kovaryans analizi için kullanılan matematik model; $Y_{i j k}=\mu+a_{i}+b_{j}+b_{1}\left(X_{i j k}-\bar{X}\right)+e_{i j k}$

$\mathrm{Bu}$ formülde yer alan terimlerden;

$\mu=$ popülasyon ortalamasını,

$\mathrm{ai}=\mathrm{i}$. kontrol sırası etki miktarını,

$\mathrm{bj}=\mathrm{j}$. Buzağılama ayı etki miktarını,

$\mathrm{b}=\log 10 \mathrm{SHS}$ ye göre ineğin süt veriminin regresyonunu,

$\mathrm{Xij}=\mathrm{j}$. ayda buzağılayan i. kontrol sırasındaki k. İneğin Log10SHS değerini,

$X=\log 10$ SHS değeri ortalamasını,

eijk = normal, bağımsız şansa bağlı hatayı temsil etmektedir.

Regresyon denklemi SAS paket programı ile oluşturulmuştur (Orhan ve ark. 2004). SHS normal dağılış göstermediği için verilere Log10 tabanına göre transformasyon uygulanmıştır. Subklinik mastitisle SHS arası ilişkilerin kurulmasında Wattiaux, (2005) bildirişlerinden yararlanılmıştır.

\section{BULGULAR ve TARTIŞMA}

\section{Çalışma Materyaline Ait Ortalama Değerler}

Süt verimi, somatik hücre sayısı ve dış yapı özelliklerine ait tanımlayıcı değerler aşağıdaki Çizelge1'de verilmiştir. Çizelge 1'de de görüldüğü gibi süt verimi, SHS ve 16 dış yapı özelliğinin dışında yaş faktörü de ele alınmıştır. Ortalamaların yanı sıra, en küçük ve en yüksek değerler, güven aralığı, varyasyon 
katsayısı ve standart sapma gibi istatiksel olarak üzerinde durulması gereken çeşitli faktörleri hesaplanmıştır.

305 günlük süt verimi ortalaması $3111 \pm 133.50 \mathrm{~kg}$ olarak tespit edilmiştir. Bu sonuç gerek yurt içinde ve gerekse yurt dışında Siyah Alaca ırkı süt sığırları için bildirilen değerlerden oldukça düşüktür. Holstein rrk1 ICAR'a üye ülkelerde iyi bakım ve beslenme koşullarında 7128 - $10967 \mathrm{~kg}$ arasında süt üretebilme kapasitesine sahip bir urktır (Erdoğdu Tatar, 2015). Türkiye'de Siyah Alaca sığırlar üzerinde yürütülen çalışmalarda 305 günlük süt verimini; Alıç ve ark. (2007) Ankara Üniversitesi Araştırma Uygulama Çiftliği'nde 4862 - 6559 kg, Polatlı Tarım İşletmesi'nde ise 6908 ile $7847 \mathrm{~kg}$ arasında, Gürses ve Bayraktar (2012) $7395.35 \pm 45.75 \mathrm{~kg}$ olarak bildirmişlerdir. $\mathrm{Bu}$ değerlerin karşılaştırılmasından da anlaşılabileceği gibi bu çalışmada 305 günlük süt verimi için tespit edilen $3111 \mathrm{~kg}$ değeri, gerek yurt içinde ve gerekse yurt dışında Holstein ırkı süt sığırları için bildirilen değerlerden oldukça düşüktür.

Çizelge 1. Çalışma materyaline ait tanımlayıcı değerler

\begin{tabular}{|c|c|c|c|c|c|c|}
\hline DEĞİŞKEN & $\mathrm{N}$ & $\mathrm{X} \pm$ S.e & Değişim Genişliği & Güven Aralığ 1 & Var. Kat. \% & Std. Sap. \\
\hline SÜT(kg) & 29 & $3111 \pm 133.50$ & $2071-4468$ & $2837.21-3384.17$ & 23.11 & 718.95 \\
\hline SHS(adet/ml) & 29 & $419.88 \pm 67.50$ & $32.70-1407$ & $281.60-558.16$ & 86.57 & 363.53 \\
\hline YAŞ(ay) & 29 & $34.86 \pm 2.49$ & $25-64$ & $29.74-39.98$ & 38.59 & 13.45 \\
\hline $\mathrm{SY}(\mathrm{cm})$ & 29 & $139.20 \pm 0.66$ & $133-146$ & $137.83-140.57$ & 2.58 & 4.59 \\
\hline ÖGG(cm) & 29 & $19.58 \pm 0.12$ & $18-20.73$ & $19.42-19.52$ & 3.50 & 0.69 \\
\hline $\mathrm{BD}(\mathrm{cm})$ & 29 & $88.93 \pm 0.73$ & $78-96$ & $87.43-90.42$ & 4.42 & 3.93 \\
\hline $\mathrm{BÇ}(\mathrm{cm})$ & 29 & $33 \pm 0.31$ & $30-37$ & $32.35-33.64$ & 5.12 & 1.69 \\
\hline $\mathrm{SG}(\mathrm{cm})$ & 29 & $18.72 \pm 0.26$ & $16-21$ & $18.18-19.26$ & 7.53 & 1.41 \\
\hline ÖMBU(cm) & 29 & $3.84 \pm 0.11$ & $2.80-5.40$ & $3.62-4.07$ & 15.50 & 0.60 \\
\hline $\mathrm{MD}(\mathrm{cm})$ & 29 & $-6.51 \pm 0.73$ & $-11-5.40$ & $-8.01--5.02$ & 60.35 & 3.93 \\
\hline $\operatorname{AMD}(\mathrm{cm})$ & 29 & $17.55 \pm 0.28$ & $15-22$ & $16.97-18.13$ & 8.69 & 1.52 \\
\hline $\mathrm{AMBU}(\mathrm{cm})$ & 29 & $4.13 \pm 0.12$ & $3-5$ & $3.87-4.40$ & 16.74 & 0.69 \\
\hline ÖMBAM(cm) & 29 & $10.27 \pm 0.47$ & $4-18$ & $9.31-11.23$ & 24.65 & 2.53 \\
\hline $\operatorname{AMBAM}(\mathrm{cm})$ & 29 & $6.51 \pm 0.43$ & $3-11$ & $5.63-7.40$ & 35.66 & 2.32 \\
\hline YMBAM(cm) & 29 & $9.10 \pm 0.40$ & $5-12$ & $8.28-9.25$ & 23.73 & 2.16 \\
\hline ÖMBÇ(cm) & 29 & $22.86 \pm 0.57$ & $17.90-30.40$ & $21.68-24.02$ & 13.46 & 3.07 \\
\hline AMBÇ $(\mathrm{cm})$ & 29 & $22.45 \pm 0.49$ & $18.40-28.40$ & $21.43-23.45$ & 11.84 & 2.65 \\
\hline ÖMBYY(cm) & 29 & $54.65 \pm 1.28$ & $38-64$ & $52.01-57.29$ & 12.67 & 6.92 \\
\hline AMBYY $(\mathrm{cm})$ & 29 & $55.58 \pm 1.26$ & $38-65$ & $52.99-58.17$ & 12.25 & 6.81 \\
\hline
\end{tabular}

N: Sayı, X: Ortalama, S.e: Standart Hat, MD: Dizden yukarı (-), Dizden Aşağı (+)

Araştırmada kullanılan hayvan materyalinin henüz 1-2. laktasyonda olması, yurt dışından ithal yoluyla getirilmiş olan materyalin henüz bölgeye adaptasyonunun tamamlanamamış olması, bakım ve beslemenin yetersiz olmasi, ayrıca materyalin bugüne kadar herhangi bir seleksiyon ve ayıklamaya tabii tutulmamıș olması süt veriminin düșük olmasına yol açmıs olabilir. SHS $32,70-1407 \times 10^{3}$ adet $/ \mathrm{ml}$ arasında değişiklik göstermiş ve ortalama SHS 419.88 $\times 10^{3}$ adet $/ \mathrm{ml}$ olarak bulunmuştur. $\mathrm{Bu}$ ortalama değer Türk Gıda Kodeksinin belirlediği somatik hücre sayısı üst limit değeri olan 500.000 adet $/ \mathrm{ml}$ ' nin altında bulunmuştur (Anonim, 2000). Bu çalışma bulgularına benzer olarak, Gökçe (2011) yaptığı çalışmasında ortalama SHS'nı 55.344 adet/ml olarak, sağlıklı bir inekte olması gereken değer aralığının içinde bulmuştur. Diğer taraftan, Göncü ve Özkütük (2002) tarafindan bildirilen 856.830 ve 2.295.150 adet $/ \mathrm{ml}$, Eyduran ve ark. (2005) tarafından Ağustos ve Kasım ayları için bildirilen 1.311.761 adet $/ \mathrm{ml} /$ inek ve 732.810 adet $/ \mathrm{ml} /$ inek değerleri gerek bu çalışmada elde edilen değerden ve gerekse $\mathrm{AB}$ normlarından daha yüksek bulunmuştur. SHS düşük olması işletmede uygulanan sağım koşullarının iyi olması, henüz ilk laktasyonda olmasının yanında hayvanların süt verimlerinin de düşük olması etkili olmuş olabilir.

Araştırma süresince $308 \mathrm{kez}$ SHS ölçümü yapılmış olup bu ölçümlerden 194 tanesinde (\%63) SHS değeri $500.000 \mathrm{adet} / \mathrm{ml}$ 'nin altında bulunmuştur. 114 ölçüm (\%27) 500.000 adet $/ \mathrm{ml} \mathrm{limitinin} \mathrm{üzerinde} \mathrm{bulunmuştur.}$ Diğer taraftan araştırmada kullanılan 29 inekten 18'inin y1llı SHS geometrik ortalamas1 400.000 adet/ml'nin altında bulunmuştur. Bu durumda sürü düzeyinde SHS 
değerinin üst değere yakın bulunması mastitis olmuş 11 inekten kaynaklanmaktadır.

\section{Günlük Süt Verimi ve SHS'na İlişkin Ortalama Değerler}

Kontrol günü süt verimine kontrol ayı ve kontrol sırasının etkisi çok önemli $(\mathrm{P}<0.01)$ bulunmuştur (Çizelge 2). Diğer yandan, SHS ve logSHS hem kontrol ayı ve hem de kontrol sırasından etkilenmemiştir.

Kontrol Sirası ve Kontrol Ayına Göre Ortalama değerler Çizelge 2'de verilmiştir.

Çizelge 2. Kontrol Sırası ve Kontrol Ayına Göre Ortalama Dağılımlar

\begin{tabular}{|c|c|c|c|c|}
\hline Genel & $\mathrm{N}$ & Kon. Süt Ver.(kg) & SHS(adet $/ \mathrm{ml})(* 1000)$ & LogSHS \\
\hline G. Ort. & 308 & $10.17 \pm 3.68$ & $737.18 \pm 32.79$ & $2.44 \pm 0.69$ \\
\hline Kontrol Ay1 & - & $* *$ & ös & ös \\
\hline Ocak & 16 & $10.81 \pm 0.83^{\mathrm{dfe}}$ & $667.0 \pm 242.36$ & $2.334 \pm 0.156$ \\
\hline Şubat & 22 & $12.79 \pm 0.79^{\mathrm{abc}}$ & $892.9 \pm 231.34$ & $2.502 \pm 0.149$ \\
\hline Mart & 24 & $14.04 \pm 0.75^{\mathrm{a}}$ & $1118.3 \pm 220.40$ & $2.557 \pm 0.142$ \\
\hline Nisan & 26 & $12.40 \pm 0.75^{\text {abc }}$ & $740.5 \pm 220.24$ & $2.310 \pm 0.142$ \\
\hline May1s & 26 & $13.26 \pm 0.73^{\mathrm{ab}}$ & $455.6 \pm 214.82$ & $2.425 \pm 0.138$ \\
\hline Haziran & 27 & $11.67 \pm 0.78^{\text {bcd }}$ & $685.9 \pm 229.23$ & $2.424 \pm 0.147$ \\
\hline Temmuz & 24 & $10.55 \pm 0.79^{\text {cde }}$ & $566.8 \pm 232.21$ & $2.404 \pm 0.149$ \\
\hline Ağustos & 23 & $9.40 \pm 0.71^{\text {tgh }}$ & $738.8 \pm 209.49$ & $2.417 \pm 0.135$ \\
\hline Eylül & 28 & $7.38 \pm 0.74^{\text {gh }}$ & $684.3 \pm 218.22$ & $2.431 \pm 0.140$ \\
\hline Ekim & 26 & $7.22 \pm 0.74^{\mathrm{gh}}$ & $669.2 \pm 218.12$ & $2.426 \pm 0.140$ \\
\hline Kasım & 26 & $6.96 \pm 0.62^{\mathrm{h}}$ & $677.4 \pm 181.60$ & $2.461 \pm 0.117$ \\
\hline Aralık & 40 & $8.18 \pm 0.94^{\mathrm{fgh}}$ & $887.7 \pm 274.37$ & $2.501 \pm 0.176$ \\
\hline Kontrol Siras1 & & ** & ös & ös \\
\hline 1 & 29 & $11.23 \pm 0.72^{\mathrm{ab}}$ & $973.3 \pm 211.71$ & $2.505 \pm 0.136$ \\
\hline 2 & 29 & $11.88 \pm 0.72^{\mathrm{a}}$ & $700.6 \pm 210.39$ & $2.415 \pm 0.135$ \\
\hline 3 & 31 & $12.34 \pm 0.69^{\mathrm{a}}$ & $558.6 \pm 202.47$ & $2.172 \pm 0.130$ \\
\hline 4 & 32 & $11.47 \pm 0.68^{\text {ab }}$ & $703.3 \pm 200.32$ & $2.517 \pm 0.129$ \\
\hline 5 & 30 & $11.23 \pm 0.70^{\mathrm{ab}}$ & $705.8 \pm 204.68$ & $2.392 \pm 0.132$ \\
\hline 6 & 29 & $10.71 \pm 0.71^{\mathrm{ab}}$ & $515.7 \pm 209.28$ & $2.406 \pm 0.135$ \\
\hline 7 & 30 & $9.52 \pm 0.70^{\mathrm{bc}}$ & $806.0 \pm 205.65$ & $2.529 \pm 0.132$ \\
\hline 8 & 30 & $8.56 \pm 0.69^{\text {cd }}$ & $677.3 \pm 204.14$ & $2.416 \pm 0.131$ \\
\hline 9 & 30 & $8.06 \pm 0.70^{\text {cd }}$ & $808.4 \pm 204.57$ & $2.487 \pm 0.131$ \\
\hline 10 & 38 & $7.42 \pm 0.65^{\mathrm{d}}$ & $889.5 \pm 189.67$ & $2.552 \pm 0.122$ \\
\hline
\end{tabular}

${ }^{\text {a,h }}$ : Aynı sütunda verilen ortalamalar arasındaki farklar istatistik olarak önemlidir $(\mathrm{P}<0.01)$

Çizelge 2'den görüleceği gibi kontrol süt verimi, SHS ve $\operatorname{logSHS}$ için en yüksek veriler Mart ayında görülmüştür. Diğer yandan kontrol süt verimi ile SHS mayıs ayında, $\operatorname{logSHS}$ ise Nisan ayında en düşük düzeyde bulunmuştur. Ancak, somatik hücre sayısı yaz aylarında diğer aylara nazaran daha yüksek olduğu ve bu durumun çevresel sıcaklık ile sığırın hormonal yapısında oluşan değişimlerden kaynaklandığı bazı araştırıcılar tarafından da bildirilmiștir (Göncü ve Öztürk, 2002; Eyduran ve ark., 2005). Süt verimi yüksek olan sığırlar mastitise daha duyarlı olmaktadır. $\mathrm{Bu}$ çalışmada kullanılan ineklerin süt veriminin düşük olması SHS'nın da düşük olmasına yol açmış olabilir. Diğer yandan SHS'nın kontrol ayı ve kontrol sırasına göre değişmemiş olması ise işletmede bakım besleme ve idari yönetim uygulamalarını mevsimlere göre değișmemiş olması ile açıklanabilir.

Şubat, Mart, Nisan ve Mayıs ayları kontrol günü süt veriminin, en üst düzeyde süt veriminin elde edildiği aylar olarak gözlemlenmektedir. Akdeniz iklim koşullarında, yaz mevsiminde görülen yüksek hava sıcaklığı ve nemin sığırların döl verimini ve süt veriminde önemli azalışlara neden olduğu önceki çalışmalardan bahsedilmiştir (Koç ve ark. 2011). Ancak, ortalama süt verimine bakıldığında bu durumun aksi yönde bir sonuç elde edilmiștir. Yaz aylarında süt veriminde azalma beklenirken, bu durumun sonbahar mevsiminde etkili olduğu görülmektedir. Çalışmada kullanılan hayvan materyalinin büyük bir kısmı sonbahar aylarında kuruya alındığı için, sonbahardaki 
süt verimlerinde kuruya ayrılmaya yakın hayvanların da sağılmasından dolayı, süt verimi düşük bulunmuştur. SHS ve $\operatorname{logSHS}$ 'nin önemsiz düzeyde bulunması, süt veriminin yüksek olmaması ve dolaysıyla süt verimini çok etkilememektedir.

\section{Süt Verimi ile Dış Yapı Özellikleri Arasındaki İlişkiler}

D1ş yap1 özelliklerinin süt verimi üzerine etkilerinin incelendiği bu bölümde, her bir özelliğin süt verimi üzerine etki miktarı tespit edilmiştir. Süt verimi ile on altı dış yapı özelliği için ölçülen değerler esas alınarak yapılan değerlendirmede de, söz konusu özelliklerin süt verimi üzerine etkileri incelenmiştir. $\mathrm{Bu}$ amaçla Stepwise çoklu regresyon yöntemi kullanılmıştır. Her adımda modele ilave edilen değişkenlerin önemlilik derecesi ve belirleme katsayısı saptanmıştır. Bu yöntemde süt verimi sabit değişken olup, süt verimi ile ilişkisi öğrenmek istenilen tüm özellikler analizde kullanılmıştır. Stepwise analizi oluşabilecek en uygun modeli aşamalı bir şekilde belirler. $\mathrm{Bu}$ aşamalar sonucunda, bazı değişkenler elenir ve sonuç olarak belirleme katsayısı en yüksek olan model, en uygun model seçilir.

305 günlük süt verimini en iyi tahmin eden modelin belirlenmesi amaciyla yürütülen Stepwise Regresyon Analizi, çalışmanın yöntem bölümünde bildirildiği gibi 5 aşamada gerçekleştirilmiştir. Her aşamada modele 305 günlük süt verimine etkilerinin önemli olduğu tespit edilen farklı bir değişken katılması suretiyle, modeldeki en uygun değişken sayısını belirleme yoluna gidilmiştir. $\mathrm{Bu}$ amaçla oluşturulan regresyon denklemi sonuçları aşamalı olarak Çizelge 3'de verilmiştir.

En uygun regresyon denklemi

$\mathrm{Y}=2207,1+80,5 \cdot \mathrm{X}_{15}+92,6 \cdot \mathrm{X}_{14}+127,1 \cdot \mathrm{X}_{10}+(-$

$110,7) \cdot \mathrm{X}_{6}+(-58,86) \cdot \mathrm{X}_{5} \quad\left(\mathrm{R}^{2}=\% 32\right)$ şeklinde olup bu

modelde yer alan terimlerden

$Y=305$ günlük süt verimini,

a: Sabit değeri,

$\mathrm{b}_{1}$ : Laktasyon süt verimine göre Ön Meme Başlarının Çapı (ÖMBÇ)'nın regresyonu,

$\mathrm{b}_{2}$ : Laktasyon süt verimine göre Yan Meme Başları Arası Mesafe (YMBAM)'ın regresyonu,

$\mathrm{b}_{3}$ : Laktasyon süt verimine göre Arka Meme Derinliği (AMD)'nin regresyonu,

$\mathrm{b}_{4}$ : Laktasyon süt verimine göre Sağrı Genişliği (SG)'nin regresyonu, ve

$\mathrm{b}_{5}$ : Laktasyon süt verimine göre Boyun Çevresi (BÇ)'nin regresyonunu,

$\mathrm{X}_{15}$ : Ön Meme Başlarının Çapı (ÖMBÇ)'nı

$\mathrm{X}_{14}$ :Yan Meme Başları Arası Mesafe (YMBAM)'yi

$\mathrm{X}_{10}$ :Arka Meme Derinliği (AMD)'ni

$\mathrm{X}_{6}$ : Sağrı Genişliği (SG)ni

$\mathrm{X}_{5}$ :Boyun Çevresi (BÇ)' ni

e: Hata terimini ifade etmektedir.

Çizelge 3. Süt Verimi ile Dış Yapı Özellikleri Arasındaki Korelasyonlar

\begin{tabular}{|c|c|c|c|c|c|c|c|c|c|c|c|c|c|c|c|c|c|c|c|c|c|c|}
\hline \multicolumn{23}{|c|}{$Y=a+b_{1} \cdot X_{1}$} \\
\hline $\mathbf{Y}$ & $=$ & $\mathbf{a}$ & + & $\mathbf{b}_{1}$ & . & $\mathbf{X}_{1}$ & + & $\mathbf{b}_{2}$ & & $\mathbf{X}_{2}$ & + & $\mathbf{b}_{3}$ & $\mathbf{X}_{3}$ & + & $\mathbf{b}_{4}$ & & $\mathbf{X}_{4}$ & + & $\mathbf{b}_{5}$ & $\mathbf{X}_{5}$ & $=$ & $\mathbf{R}^{2}$ \\
\hline $\mathbf{Y}$ & $=$ & 990.2 & + & $92.6^{*}$ & . & $X_{15}$ & & & & & & & & & & & & & & & $=$ & $15 \%$ \\
\hline $\mathbf{Y}$ & $=$ & 646.1 & + & 79.6 & . & $X_{14}$ & + & 75.9 & & $\mathbf{X}_{15}$ & & & & & & & & & & & $=$ & $20 \%$ \\
\hline $\mathbf{Y}$ & $=$ & $-1467,8$ & + & 116.9 & . & $\mathbf{X}_{10}$ & + & 104.8 & & $\mathbf{X}_{14}$ & + & 68.6 & $\mathbf{X}_{15}$ & & & & & & & & $=$ & $26 \%$ \\
\hline $\mathbf{Y}$ & $=$ & 48.9 & + & $-105,7$ & . & $X_{6}$ & + & 137.16 & . & $\mathbf{X}_{10}$ & + & 105.87 & $X_{14}$ & + & 72.93 & & $X_{15}$ & & & & $=$ & $30 \%$ \\
\hline $\mathbf{Y}$ & $=$ & 2207.1 & + & $-58,86$ & & $\mathbf{X}_{5}$ & + & $-110,7$ & & $X_{6}$ & + & 127.1 & $\mathbf{X}_{10}$ & + & 92.6 & & $\mathbf{X}_{14}$ & + & 80.5 & $X_{15}$ & $=$ & $32 \%$ \\
\hline
\end{tabular}

Değerlendirmeye alınan 16 tip özelliğinin her birinin 305 günlük süt verimine olan etkisi analiz edilmiştir. Stepwise Regresyon analiz yöntemi 5. aşamada sonuçlanmıştır. Sonuç olarak 5 farklı tip özelliğin etkisi önemli sayılabilecek düzeyde bulunmuştur. Çizelge 3 'de görüldüğü gibi model de en fazla etki ve öneme $\mathrm{BÇ}$ faktörünün eklenmesiyle ulaşıldığı görülmektedir. $\mathrm{Bu}$ araştırmada ÖMBÇ, YMBAM, AMD, SG ve BÇ değişkenleri sırayla modele eklenerek en yüksek $\mathrm{R}^{2}$ değeri elde edilmiştir. Bu tip özelliklerinden en önemli etkiyi ÖMBÇ $(\mathrm{P}<0.05)$ göstermiştir. Yani, süt verimi ile ÖMBÇ özelliği arasında pozitif ilişkiler olduğu tespit edilmiştir. Diğer yandan süt verimi ile YMBAM, AMD, $\mathrm{SG}$ ve $\mathrm{BÇ}$ arasında ise önemli bir ilişki bulunmamıştır.

Belirleme katsayısından $\left(\mathrm{R}^{2}\right)$ yola çıkılarak en iyi modele $\left(\mathrm{R}^{2}=\% 32\right)$, tüm faktörlerin modele dahil edilmesiyle elde edilmiştir. İlk aşamada ÖMBÇ'nın laktasyon süt verimine göre regresyon katsayısı $92.6\left(\mathrm{R}^{2}\right.$ $=\% 15$ ) bulunmuş, ikinci aşamada YMBAM' nin de modele dahil edilmesiyle belirleme katsayıs1 \% 20'ye, sonraki aşamada AMD'nin modele eklenmesiyle bu değer \%26'ya ulaşmıştır. Dördüncü aşamada SG modele ilavesi ile \%30 olan belirleme katsayısı beşinci ve son adımda BÇ'nin modele dahil olmasıyla belirleme katsayısı en yüksek değer olan $\% 32$ seviyesine ulaşılmıştır.

Vücut ölçülerinden ÖMBÇ' nin süt verimi ile ilişkisi pozitif ve önemli $(\mathrm{P}<0.01)$, SG ve $\mathrm{BÇ}$ 'nin süt verimi ile ilişkisi negatif yönde önemsiz, YMBAM ve AMD ilişkisi pozitif ancak önemsiz bulunmuştur. Süt verimi ile ÖMBÇ arasında önemli bir ilişki bulunmamıştır (P>0.05). (Çizelge 3). 
Yüksek düzeyde süt, et ve döl verimine sahip, dayanıklı ve uzun ömürlü hayvanların tespiti doğrusal tip özelliklerinin sinıflandırılmasıyla mümkün olabilmekte ve bu durum karlılığı olumlu yönde etkilemektedir.

Süt sığırlarında vücut büyüklüğü, başta süt verimi olmak üzere diğer özelliklere etkili olması nedeniyle önemlidir. Bundan dolayı, sağrı yüksekliği (SY), göğüs genişliği (GG) ve beden derinliği (BD) gibi özelliklerin süt verimi üzerinde etkili olması beklenilen bir durumdur.

Çalışma sonuçları Berry ve ark. (2004), Ceyhan ve ark. (2013) ve Alıç ve ark., (2007 bildirdiği süt verimi ile vücut ölçüleri arasında ilişki olduğu sonuçlara benzer bulunmuştur.

\section{SHS ile Dış Yapı Özellikleri Arasındaki İlişkiler}

SHS ile dış yapı özellikleri arasındaki ilişkiyi en iyi tahmin eden modelin belirlenmesi amaciyla yürütülen Stepwise Regresyon Analizi Çizelge 4'de verilmiştir.

SHS'na etkili meme ve vücut ölçülerinin belirlenmesi amaciyla yürütülen Stepwise Regresyon analizi de altıncı aşamada sonuçlanmıştır. Belirleme katsayısından $\left(\mathrm{R}^{2}\right)$ yola çıkılarak en iyi model $\left(\mathrm{R}^{2}=\% 38\right)$, altı değişkenin modele dahil edilmesiyle elde edilmiştir.

Her aşamada modele SHS' na etkileri önemli bulunan farklı bir değişkenin katılması ile modeldeki en uygun değişken sayısının belirlenmesi yoluna gidilmiştir. Bu amaçla oluşan regresyon modeli
"Y $=-884+57 * \cdot \mathrm{X}_{1}+(-41) \cdot \mathrm{X} 2+(-131) \cdot \mathrm{X} 3+(-$

75).X4+90.X5+8.X6" şeklinde olmuştur.

$\mathrm{Bu}$ modelde yer alan terimlerden,

$\mathrm{Y}=$ SHS'yi

a: Sabit değeri,

$\mathrm{b}_{1}$ : SHS değerine göre ÖMBÇ’nin regresyonunu,

$\mathrm{b}_{2}$ : SHS değerine göre AMBAM'ın regresyonunu,

$b_{3}$ : SHS değerine göre AMBU'nun regresyonunu,

$\mathrm{b}_{4}$ : SHS değerine göre MD'nin regresyonunu,

$\mathrm{b}_{5}$ : SHS değerine göre SG'nin regresyonunu ve

$\mathrm{b}_{6}$ : SHS değerine göre YAŞ değişkeninin regresyon

katsayılarını,

$\mathrm{X}_{1}$ :Ön Meme Başları Çapı (ÖMBÇ)'nı

$\mathrm{X}_{2}$ : Arka Meme Başları Arası Mesafe (AMBAM)'yi

$\mathrm{X}_{3}$ : Arka Meme Başları Uzunluğu (AMBU)' nu

$\mathrm{X}_{4}$ :Meme Derinliği (MD)'ni

$\mathrm{X}_{5}$ : Sağrı Genişliği (SG)'ni

$\mathrm{X}_{6}:$ Yaş' $1^{\prime}$

e: Hata terimini ifade etmektedir.

SHS'nı etkileyen faktörlerin incelendiği analizde modele tüm değişkenlerin sirayla eklenmesiyle en yüksek $\mathrm{R}^{2}$ değeri altıncı aşamada elde edilmiștir. Yukarıda verilen çizelgeye bakıldığında aşamalı olarak her seferinde modele bir değişken eklenmiştir, çizelgede görüldüğü gibi ÖMBÇ, AMBAM ve AMBU değişkenlerin regresyon analizine dahil olmasıyla modele ait $\mathrm{R}^{2}$ değeri, en yüksek $\mathrm{R}^{2}$ değeri olan \%38'lik değer elde edildiği görülmektedir.

Çizelge 4. SHS ile Dış Yapı Özellikleri Arasındaki Korelasyonlar

\begin{tabular}{|c|c|c|c|c|c|c|c|c|c|c|c|c|c|c|c|c|c|c|c|c|c|c|}
\hline \multicolumn{23}{|c|}{$Y=a+b_{1} \cdot X_{1}$} \\
\hline $\mathbf{Y}$ & $=$ & $\mathbf{a}$ & + & $b_{1}$ & $\mathbf{X}_{1}$ & + & $\mathbf{b}_{2}$ & $\mathbf{X}_{2}$ & + & $\mathbf{b}_{3}$ & $\mathbf{X}_{3}$ & + & $\mathbf{b}_{4}$ & $\mathbf{X}_{4}$ & + & $\mathbf{b}_{5}$ & $\mathbf{X}_{5}$ & + & $b_{6}$ & $X_{6}$ & $=$ & $\mathbf{R}^{2}$ \\
\hline$Y$ & $=$ & -142 & + & $10 *$ & $\mathrm{X}_{1}$ & & & & & & & & & & & & & & & & $=$ & $11 \%$ \\
\hline $\mathbf{Y}$ & $=$ & -864 & + & 36 & $\mathrm{X}_{1}$ & + & 8 & $\mathbf{X}_{2}$ & & & & & & & & & & & & & $=$ & $18 \%$ \\
\hline $\mathbf{Y}$ & $=$ & 285 & + & 38 & $X_{1}$ & + & -68 & $\mathbf{X}_{2}$ & + & 8,6 & $\mathbf{X}_{3}$ & & & & & & & & & & $=$ & $25 \%$ \\
\hline $\mathbf{Y}$ & $=$ & -800 & + & 37 & $X_{1}$ & + & $-93 *$ & $\mathbf{X}_{2}$ & + & $90 *$ & $\mathbf{X}_{3}$ & + & 6 & $\mathbf{X}_{4}$ & & & & & & & $=$ & $32 \%$ \\
\hline $\mathbf{Y}$ & $=$ & -840 & + & 42 & $\mathrm{X}_{1}$ & + & -108 & $X_{2}$ & + & -77 & $\mathbf{X}_{3}$ & + & 92 & $\mathbf{X}_{4}$ & + & 1 & $\mathbf{X}_{5}$ & & & & $=$ & $35 \%$ \\
\hline $\mathbf{Y}$ & $=$ & -884 & + & $57 *$ & $\mathbf{X}_{1}$ & + & -41 & $\mathbf{X}_{2}$ & + & -131 & $X_{3}$ & + & -75 & $\mathbf{X}_{4}$ & + & 90 & $\mathbf{X}_{5}$ & + & 8 & $X_{6}$ & $=$ & $38 \%$ \\
\hline
\end{tabular}

Vücut ve meme ölçülerinden ÖMBÇ’nin SHS ile ilişkisi pozitif ve önemli, SG ve YAŞ’ın SHS ilişkisi pozitif ancak önemsiz, AMBAM, AMBU ve MD'nin ile ilişkisi ise negatif ve önemsiz bulunmuştur.

Dolayısıyla SHS'^ üzerinde ÖMBÇ, AMBAM ve AMBU özelliklerinin önemli etkisi olduğu görülmektedir $(\mathrm{P}<0.05)$. Bu çalışmada $\mathrm{MD}, \mathrm{SG}$ ve YAŞ' tan oluşan özelliklerin ise SHS'yı önemli sayılmayacak düzeyde etkilediği görülmektedir. Sonuçtan da anlaşılabileceği gibi SHS ile meme ölçüleri doğrudan ilişkilidir. Meme ve meme başlarının hijyeni SHS'nı önemli düzeyde etkilemektedir.

$\mathrm{Bu}$ araştırma bulgularına benzer olarak, Holstein ırk1 sığırları üzerinde daha önce yürütülmüş olan çalışmalarda, yerden daha yüksek meme yapısına sahip
Sığırların sütlerinde SHS' nın daha düşük düzeylerde olduğu, yine SHS ve meme derinliği arasında yüksek genetik korelasyonların olduğu, özellikle de meme başı uzunluğu ve SHS arasında pozitif yönde bir ilişki olduğu ifade edilmiştir (Rogers ve ark., (1991).

$\mathrm{Bu}$ araştırmada elde edilen bulguların aksine Holstein 1rkı üzerinde, Göncü ve ark., (2002) meme loblarının SHS'na etkisini önemsiz olarak bildirirken, Juozaitiene ve ark., (2006) meme ve meme baş1 özelliklerinin SHS üzerindeki etkisini önemli $(\mathrm{P}<0.001)$, Gökçe, (2011) arka meme yüksekliği ile somatik hücre sayısı arasında negatif yönde ve istatistiki olarak önemli $(\mathrm{P}<0.05)$ bir korelasyon bulmuştur.

Diğer bir yandan, bu çalışma ile benzer bir şekilde Dadpasand ve ark., (2012) Holstein sı̆̆ırlarda SHS ile 
meme derinliği arasında negatif yönlü genetik bir ilişkinin olduğunu, aynı şekilde SHS ile meme çapı arasındaki genetik korelasyonu ise pozitif yönde ve önemli $(\mathrm{P}<0.05)$ olarak bulmuşlardır. $\mathrm{Bu}$ çalışmanın aksine Gökçe (2011)'de meme derinliği ile SHS arasındaki ilişkiyi önemli $(\mathrm{P}<0.05)$ bulmuştur, fakat bu çalışmanın analiz sonucuna istinaden yukarıda belirtildiği gibi MD ile SHS arasında negatif yönde ve istatistiki olarak önemsiz sonuç elde edilmiştir. Genel olarak analizde, doğrusal tanımlama kapsamındaki özellikler ile SHS arasındaki korelasyonlardan elde edilen bu sonuçların birçok araştırıcının sonuçlarını doğrular nitelikte olduğu görülmektedir.

Kontrol Süt Verimi, SHS ve logSHS Arasındaki Korelasyonlar

Kontrol günü süt verimi ve logSHS arasındaki korelasyonlar Çizelge 5'de verilmiştir.
Çizelge 5. Kontrol Günü Süt Verimi ve logSHS Korelasyonlar1

\begin{tabular}{|l|l|l|} 
& SHS & LogSHS \\
\hline SÜT & -0.05943 & -0.09391 \\
\hline SHS & & $0.76677^{* *}$ \\
\hline
\end{tabular}

** $\mathrm{P}<0.01$

SHS, $\log$ SHS ve Süt verimi arasındaki korelasyonlar incelendiğinde SHS ile logSHS arasında doğrusal artan kuvvetli bir ilişki görülmektedir ( $r=0,76677)$ ve istatiksel olarak çok önemli $(\mathrm{P}<0.01)$ bulunmuştur.

Diğer yandan süt verimi ile SHS ve $\operatorname{logSHS}$ arasındaki korelasyonlar negatif yönlü ve önemsiz bulunmuştur. Popülasyon genelinde süt veriminin düşük olması süt verimi-SHS arasındaki korelasyonlarında düşük çıkmasına neden olmuş olabilir.

Kontrol Süt Verimi ile SHS Arasındaki İlişkiler

Kontrol süt verimi ile SHS arasındaki ilişkiler Çizelge 6'da verilmiştir.

Çizelge 6. Kontrol Süt Verimi ve SHS Korelasyonları

\begin{tabular}{|l|c|c|c|c|c|}
\hline Değişken & SD & Parametre Tahmini & Std. Hata(S.e) & t Değeri & Pr $>t$ \\
\hline Intercept & 1 & 10.36184 & 0.30852 & 33.59 & $<0.0001$ \\
\hline SHS & 1 & -0.00024948 & 0.00023955 & -1.04 & 0.2985 \\
\hline
\end{tabular}

Çizelge 6'da görüleceği gibi somatik hücre sayısına göre kontrol günü süt veriminin regresyonu -0.00025 olarak bulunmuştur.

Popülasyon düzeyinde SHS'nın $419 * 10^{3}$ adet $/ \mathrm{ml}$ olduğu göz önüne alındığında kontrol günü süt veriminde günlük 104 gr'lı ( $\%$ 1.04) kayıp söz konusudur. İnek başına 305 günlük süt verimindeki kayıp ise $32 \mathrm{~kg}$ 'dır.

\footnotetext{
Kontrol Günü Süt Verimi ile logSHS Arasındaki İlişkiler:

Kontrol süt verimi ve $\operatorname{logSHS}$ arasındaki ilişkiler Çizelge 7'de verilmiştir.

Kontrol günü süt verimi ile $\operatorname{logSHS}$ arasında önemsiz bir ilişki bulunmuştur. Bu çalışmada önemli süt kayıpları görülmemektedir. Bunun nedeni, popülasyonda süt veriminin düşük olmasından kaynaklanmaktadır.
}

Süt Verimi, SHS, Yaș ve Dıș Yapı Özellikleri Arasındaki Korelasyonlar

Süt verimi, somatik hücre yapısı ve dış yap1 özellikleri ile ilgili ilişkiler çizelge 8'de verilmiştir.

Yapılan çalıșmada birbirini etkileyen değişkenler arasındaki ilişkiler korelasyon analizi yapılarak incelenmiştir. $\mathrm{Bu}$ özellikler arasındaki korelasyonlar Çizelge 8'de verilmiştir.

$\mathrm{Bu}$ çalışmada en yüksek korelasyon ÖMBYY ile AMBYY arasında $(0,96)$, en düşük korelasyon ise AMBYY ile ÖMBAM arasında $(-0,75)$ gerçekleşmiştir. SHS ile meme derinliği arasında tespit edilen 0.30'luk genetik korelasyon değeri, SHS 'nın ön ve arka meme başları çapı arasında tespit edilen 0.26 ve 0.25 'lik genetik korelasyon değerleri Dadpasand ve ark. (2012) tarafindan sirasiyla bildirilen -0.32 ve 0.34 değerlerinden daha düşük bulunmuştur.

Çizelge 7. Kontrol Günü Süt Verimi ve logSHS İlișkileri

\begin{tabular}{|l|c|c|c|c|c|}
\hline Değişken & SD & Parametre Tahmini & Standart Hata & t Değeri & Pr $>\mathrm{t}$ \\
\hline Intercept & 1 & 11.67414 & 0.94124 & 12.40 & $<0.0001$ \\
\hline LogSHS & 1 & -0.61268 & 0.37132 & -1.65 & 0.1000 \\
\hline
\end{tabular}


Çizelge 8. Süt Verimi, SHS, Yaş ve Dış Yapı Özellikleri Arasındaki Fenotipik Korelasyonlar ${ }^{\mathrm{a}}$

\begin{tabular}{|c|c|c|c|c|c|c|c|c|c|c|c|c|c|c|c|c|c|c|}
\hline DEǦișKENLIR & SüT & SHS & YASS & SY & GG & BD & $\mathrm{BC}$ & SG & ÖMBU & MD & AMD & AMBU & ÖMBAM & AMBAM & YMBAM & ÖMBC & AMBC & ÖMBYY \\
\hline SHS & 0,09098 & & & & & & & & & & & & & & & & & \\
\hline YAS & 0,34219 & $0,36900^{*}$ & & & & & & & & & & & & & & & & \\
\hline SY & $-0,1475$ & 0,01077 & 0,04854 & & & & & & & & & & & & & & & \\
\hline GG & $-0,0154$ & 0,17234 & 0,0265 & 0,33492 & & & & & & & & & & & & & & \\
\hline BD & $-0,147$ & 0,31305 & 0,21828 & 0,40939 * & 0,24055 & & & & & & & & & & & & & \\
\hline $\mathrm{BC}$ & $-0,1461$ & $-0,0143$ & $-0,25909$ & 0,25828 & 0,32761 & 0,06978 & & & & & & & & & & & & \\
\hline SG & $-0,1208$ & $0,43019^{*}$ & 0,12579 & 0,00461 & 0,18647 & $0,43994^{*}$ & $-0,07484$ & & & & & & & & & & & \\
\hline ÖMBU & 0,00991 & $0,52524^{\star *}$ & 0,32466 & 0,1968 & 0,12105 & 0,29245 & 0,0562 & $0,53242^{* *}$ & & & & & & & & & & \\
\hline MD & 0,06853 & 0,29809 & $0,45677^{*}$ & $-0,26208$ & 0,08936 & 0,2767 & 0,04834 & 0,15348 & 0,33013 & & & & & & & & & \\
\hline AIID & 0,17444 & $-0,24408$ & $-0,11794$ & 0,01099 & 0,24123 & $-0,0648$ & $-0,08309$ & 0,20586 & $-0,24584$ & $-0,2245$ & & & & & & & & \\
\hline AMBU & 0,23687 & $-0,07082$ & 0,0519 & 0,24586 & 0,3069 & 0,14762 & $-0,06097$ & 0,07679 & 0,09601 & 0,22362 & $0,43213^{*}$ & & & & & & & \\
\hline ÖMBAM & 0,28379 & 0,27414 & $0,38033^{*}$ & $-0,18269$ & 0,09354 & 0,0342 & $-0,20012$ & 0,16182 & 0,40631 & $0,70635^{* *}$ & \begin{tabular}{|l|}
$-0,05001$ \\
\end{tabular} & 0,38429 * & & & & & & \\
\hline AMBAM & 0,20003 & 0,13892 & 0,2125 & $(-0,36760)^{*}$ & $-0,10938$ & $-0,20677$ & 0,09091 & 0,0777 & 0,29704 & $0,37800^{*}$ & $-0,033$ & $-0,00153$ & 0,47218 ** & & & & & \\
\hline YMBAM & 0,33598 & 0,19438 & 0,15531 & $-0,19115$ & $-0,17123$ & 0,03866 & $-0,7604$ & $-0,01373$ & 0,03478 & 0,34693 & $-0,26715$ & $-0,05758$ & $0,52302^{*}$ & 0,44419 * & & & & \\
\hline ÖMBCุ & $0,38782 *$ & 0,25828 & 0,21443 & 0,03496 & 0,33904 & $-0,05476$ & 0,15646 & 0,11397 & $0,39519^{*}$ & 0,14267 & 0,04381 & 0,18688 & 0,36543 & $0,55211^{* *}$ & 0,28201 & & & \\
\hline AMBC̣ & 0,31876 & 0,25339 & $0,39590^{*}$ & $-0,03839$ & 0,21628 & $-0,01639$ & $-0,03893$ & 0,14542 & $0,38368^{*}$ & 0,3541 & \begin{tabular}{|l|}
$-0,04905$ \\
\end{tabular} & 0,24622 & $0,47649 * *$ & $0,69148^{* *}$ & 0,27135 & $0,70642^{* *}$ & & \\
\hline ÖMBYY & $-0,2683$ & $-0,32494$ & $(-0,49042)^{* *}$ & $0,37238^{*}$ & $-0,0741$ & $-0,07553$ & 0,26222 & $-0,23644$ & $-0,33202$ & $(-0,70775)^{* *}$ & $-0,01514$ & $-0,13104$ & $(-0,73675)^{* *}$ & $(-0,63828)^{* *}$ & $(-0, \mathbf{5 0 8 0 4})^{* \star}$ & $(-0,49835)^{*}$ & $(-0,68390)^{* *}$ & \\
\hline AMBYY & $-0,2284$ & $-0,35434$ & $(-0,46125)^{\star}$ & 0,31244 & $-0,10335$ & -10633 & 0,21094 & $-0,24259$ & $(-0,39279)^{\star}$ & $(-0,71076)^{* *}$ & 0,12586 & $-0,0934$ & $(-0,75462)^{* *}$ & $(-0,64703)^{\star *}$ & $(-0,53335)^{* \star}$ & $(-0,54836)^{\star \star}$ & $(-0,75217)^{\star *}$ & $0,96312^{* *}$ \\
\hline
\end{tabular}

${ }^{\text {a }}$ : Kısaltmalar Çizelge 1'de verilmiştir. **: çok önemli, *: önemlidir. 
Çalışmada SHS ile meme derinliği arasında tespit edilen 0.30 ' luk genetik korelasyon değeri, SHS 'nın ön ve arka meme başları çapı arasında tespit edilen 0.26 ve 0.25 'lik genetik korelasyon değerleri Dadpasand ve ark. (2012) tarafindan sirasiyla bildirilen -0.32 ve 0.34 değerlerinden daha düşük bulunmuştur. Ayrıca, De Haas ve Kadarmideen (2005)' nin araștırmalarındaki SHS ve meme derinliği arasındaki genetik korelasyon 0.31 olarak bulunmuştur.

Juozaitiene ve ark. (2006) ise SHS'nın meme ve meme başı özellikleri üzerinde çok önemli etki gösterdiğini bildirmişlerdir $(\mathrm{P}<0.01)$. Bu çalışmada $\mathrm{MD}$, ÖMBAM, AMBAM, YMBAM değişkenleri ile SHS' nın korelasyonları arasında herhangi önemli bir etki söz konusu değildir. Ayrıca, çizelgede belirtilmek üzere SHS ile BD ve GG arasinda genetik korelasyonlar sirasiyla 0,32 ve 0,16 olarak önemsiz bulunmuştur.

Literatür bildirişlerinden Ural, (2013) ise $\log 10$ SHS ile arka meme başı çevresi arasındaki korelasyonu (0.12 ) negatif fakat istatistiki olarak önemli bulmuştur $(\mathrm{P}<0.01)$. Bu çalışmada, SHS ile AMD arasındaki genetik korelasyon -0.24 negatif yönlü ve önemsiz bulunmuştur. Bu durumun aksine Gökçe (2011) SHS ile AMD arasında negatif yönlü ama önemli bir korelasyon tespit etmiştir $(\mathrm{P}<0.05)$.

Çizelge 8 'den de izlendiği gibi süt verimi ile meme derinliği arasında 0.06 ' $1 \mathrm{k}$ bir fenotipik korelasyon tespit edilmiştir. Yalnız, De Haas ve Kadarmideen (2005) araştırmalarında süt verimi ile meme derinliği arasındaki fenotipik korelasyonu -0.23 negatif yönlü olarak bulmuşlardır. Türkiye'de yapılan bir çalışmada Ceyhan ve ark., (2013), süt verimi ile ÖMBAM, YMBAM, ÖMBYY, ÖMBÇ, AMBÇ ve AMBAM arasındaki fenotipik korelasyonları önemli $(\mathrm{P}<0.01$, $\mathrm{P}<0.05)$, AMBU ve AMBYY'nin süt veriminin fenotpik korelasyonlarını ise önemsiz $(\mathrm{P}>0.05)$ olarak bildirmişlerdir. $\mathrm{Bu}$ çalışmadaki aynı doğrusal tip özelliklerin (ÖMBAM, YMBAM, ÖMBYY, ÖMBÇ, AMBÇ, AMBAM, ÖMBU, AMBU ve AMBYY) süt verimi arasındaki genetik korelasyonlara bakıldığında ise, önemsiz bir etki görülmektedir.

\section{SONUC ve ÖNERİLER}

Bazı dış yapı özelliklerinin incelendiği bu çalışmada, laktasyondaki sığırların çoğunluğu ideal sayılan yüksekliğe yakın bir sağrı yüksekliğine sahip olup, $\mathrm{GG}$, SG, ÖMBU, BD, BÇ, AMBU, ÖMBAM, AMBAM, YMBAM, ÖMBÇ, AMBÇ, ÖMBYY ve AMBYY özellikleri ise orta düzeyde bulunmuştur. Bu özelliklerin aksine MD ideal sayılan yüksekliğin çok alt sınırında bir değerdeyken, AMD ise ideal yüksekliğin üzerinde bulunmuştur.

Süt verimi, SHS miktarı ve bazı dış yapı özelliklerinin belirlenmesi ve ilişkilerinin incelendiği bu çalışmada 305 günlük süt verimi genel ortalaması $3111 \pm 133.5 \mathrm{~kg}$, somatik hücre sayıs ortalaması $419.88 \pm 67.5^{*} 10^{3}$ hücre/ml ve $\operatorname{logSHS}$ değeri $2.44 \pm 0.69$ olarak bulunmuştur. 2012 yılı Mayıs ayına ait genel ortalama SHS değeri sığır başına $455.6 \pm 214.8^{*} 10^{3}$ adet $/ \mathrm{ml}, 2012$ yılı Mart ayına ait bu değer $1118.3 \pm 220.4 * 10^{3}$ adet $/ \mathrm{ml}$ olarak bulunmuştur. Mart ayına ait ortalama SHS değeri, Mayıs ayının yaklaşık üç katı kadardır. Bu değerler sağlıklı bir sığırda olması gereken $200.000 \mathrm{adet} / \mathrm{ml}$ değerinden oldukça yüksektir. SHS' nın yüksek olduğu, dolayısıyla sütün elde edilmesinde hijyenik şartlara yeterince uyulmadı̆̆ da sığırların meme sağlığı ile ilgili problemlerinin olduğu ortaya çıkmaktadır. SHS' nın yüksek olduğu, dolayısıyla sütün elde edilmesinde hijyenik şartlara yeterince uyulmadığı, ya da sığırların meme sağlığı ile ilgili problemlerinin olduğu ortaya çıkmaktadır.

Çalışmanın yürütüldüğ̈̈ çiftlikte besleme, bakımyönetim faktörlerinin sığır verimlerini önemli ölçüde etkilediği, söz konusu faktörlere ek olarak sağım yöntemi ve hijyenin üretilen sütün kalitesinde (SHS miktarı) de önemli olduğu tespit edilmiştir.

Doğrusal tip özelliklerinin değerlendirilmesi sonucu bir sığır popülasyonunda sürüden hangi sığırların çıkarılması ve nedenlerinin belirlenmesi önemlidir. $\mathrm{Bu}$ yöntem sürüden ayıklama oranını düşürmeye bir önlem olarak değerlendirilebilir. Meme özellikleri bakımından doğru seçim yapılması somatik hücre sayısı ve meme enfeksiyonlarını önleyebilir.

$\mathrm{Bu}$ çalışmanın sonuçlarına dayanarak, yapılacak bir sığır ıslah çalışmasında seleksiyon kriteri olarak verim özellikleri, SHS değeri ve dış yapı özellikleri birlikte ele alınması gerektiği söylenebilir.

Sonuç olarak süt sı̆̆ırlarında yapılacak olan islah veya seleksiyon çalışmalarında başarı süt üretimini arttırmak, SHS için belirtilen üst limit değerin altında tutmak için, süt verim özelliklerinin yanında dış yapı özelliklerinin de 1slah veya seleksiyon programlarına ilave edilmesi önerilebilir.

\section{TEŞEKKÜR}

Yüksek lisans tezimi ve bu makaleyi ürettiğim 2013/2-11 YLS kodlu Bilimsel Araştırma Projesi'ni finansal olarak destekleyen Kahramanmaraş Sütçü İmam Üniversitesi Rektörlüğü'ne ve Bilimsel Araştırma Etik Kurulu'na teşekkürlerimi sunarım.

\section{KAYNAKLAR}

Alıç, D. 2007. Siyah Alaca İneklerde Dış Yapı Özellikleri, Sürüde Kalma Süresi ve Süt Verimi Üzerine Araştırmalar. Doktora Tezi. Ankara Üniversitesi, Fen Bilimleri Enstitüsü Zootekni Anabilim Dal1, Ankara.

Anonim. 2012. De Laval Somatik Hücre Ölçüm Cihazı DCC.

http://www.delaval.com.tr/VProducts/Milking/Cellcounter-DCC/default.htm

Anonim. 2000. Türk Gıda Kodeksi Cị̆ Süt Ve Isıl İşlem Görmüş İçme Sütleri Tebliği. Tarih: Gazete. 14.02.2000/23964, Tebliğ No:2000-6, 2000. 
Aytekin, İ., Boztepe, S. 2014. Süt Sığırlarında Somatik Hücre Sayısı, Önemi ve Etki Eden Faktörler. Türk Tarım - Gıda Bilim ve Teknoloji Dergisi, 2(3): 112121, 2014.

Berry, D.P., Buckley, F., Dillon, P., Evans, R.D., Veerkamp, R.F. 2004. Genetic Relationships Among Linear Type Traits, Milk Yield, Body Weight, Fertility and Somatic Cell Count in Primiparous Dairy Cows. Irish Journal of Agricultural and Food Research 43: 161-176, 200.

Ceyhan, A., Çınar, M., Serbester, U. 2013. Siyah Alaca İneklerde Meme Ölçülerinin Somatik Hücre Sayısı ve Süt Verimi Üzerine Etkisi. IV. Süt ve Süt Hayvancilığı Öğrenci Kongresi, 17 Mayıs 2013, Karacabey-Bursa.

Çoban, Ö., Sabuncuoğlu, N., Tüzemen, N., 2007. Meme ve Meme Başı Özelliklerinin Sütteki Somatik Hücre Sayısıyla İlişkileri. Lalahan Hayvancılık Araştırma Enstitüsü Dergisi, 2: 15-20.

Dadpasand, M., Zamiri, M.J., Atashi, H., Akhlaghi, A., 2012. Genetic Relationship of Conformation Traits with Average Somatic Cell Score at 150 and 305 Days in Milk in Holstein Cows of Iran. Journal of Dairy Science, 95(12):7340-5. doi: 10.3168/jds.2011-5002. Epub 2012 Sep 19.

De Haas, Y., Kadarmideen, H. N., 2005. Genetic Parameters for Predictors of Body Weight, Production Traits and Somatic Cell Count in Swiss Dairy Cows. Swiss Federal Institute of Technology Zurich, Institute of Animal Sciences, Statistical Animal Genetics Group, CH-8092 Zurich, Switzerland.

Erdoğdu Tatar, G. 2015. Irklarımızı Tanıyalım HolsteinSiyah Alaca. Türkiye Damızlık Sığır Yetiştirici Merkez Birliği. Damızlık Sığır Yetiştiricileri Dergisi Mart-Nisan 2015, Sf. No: 42-43.

http://www.dsymb.org.tr/2015martnisan/2015martnisan. html

Eyduran, E., Özdemir, T., Yazgan, K., Keskin, S., 2005.Siyah Alaca İnek Sütündeki Somatik Hücre Sayısına Laktasyon Sırası ve Dönemin Etkisi. YYÜ. Vet. Fak Derg. 16(1):61-65.

Gökçe, G., 2011. Çukurova Bölgesi Entansif Süt Sığırı İşletmelerindeki İlkine Doğuran Siyah Alacalarda Somatik Hücre Sayısına Etki Eden Bazı Tip, Sağım ve Amenajman Özellikleri Arası İlişkiler. Doktora Tezi. Ç.Ü. Fen Bilimleri Enstitüsü Zootekni ABD.
Göncü, S., Özkütük, K., 2002. Adana Entansif Süt Sı ğırcılığı İşletmelerinde Yetiştirilen Saf ve Melez Siyah Alaca İnek Sütlerinde Somatik Hücre Sayısına Etki Eden Faktörler ve Mastitis ile İlişkisi Hayvansal Üretim 43(2): 44-53.

Gürses, M., Bayraktar, M., 2012.Türkiye'de Farklı Bölgelerde Yetiştirilen Holştayn Sığırlarda Bazı Süt ve Döl Verimi Özellikleri. Kafkas Univ. Vet. Fak Dergisi, 18 (2): 273-280.

ICAR - International Committee for Animal Recording (2003): Guidelines Approved by the General Assembly Held in Interlaken, Switzerland, on 30 May 2002, Roma, 19 - 39.

Juozaitiene, V., Juozaitis, A., Micikeviciene, R., 2006. Relationship Between Somatic Cell Count and Milk Production or Morphological Traits of Udder in Black-and-White Cows. Turkish Journal of Veterinary and Animal Sciences, 30 (2006) 47-51.

Larroque, H., Ducrocq, V., 2001. Relationship Between Type and Longevity in the Holstein Breed. Genet. Sel. Evol. 33:39-59.

Orhan, H., Efe, E., Sahin, M. 2004. SAS Yazılımı İle İstatistik Yazılımlar. Tuğra Ofset, Isparta, $122 \mathrm{~s}$.

Rogers, G.W., Hargrove, G.L., Lawlor, T.J., Ebersole, J.L., 1991. Correlations Among Linear Traits and Somatic Cell Count. J. Dairy Sci. 74:1087-1091.

Şahin, O., 2015. Süt Sığırlarında Tip Sınıflandırması ve Vücut Kondisyonu Değerlendirme. TDSYMB Yay.

TÜIK, Hayvansal Üretim İstatistikleri, 2014

http://tuikapp.tuik.gov.tr/hayvancilikapp/hayvancilik.zul

Ural, D.A., 2013. The Relationships Among Some Udder Traits and Somatic Cell Count in HolsteinFriesian Cows. Kafkas Üniversitesi Veteriner Fakültesi Dergisi, 19(4): 601-606.

Wattalux, M.A. 2005. Prevention and detection. Dairy Essentials Chap.: 24 (93-96). Babcock Institute for International Dairy Research and Development. WI 53706, USA. http://babcock. wisc.edu/node/218.

Yalçın, C., Cevger, Y., Türkyılmaz, K., Uysal, G., 2000. Estimation of Milk Yield Losses From Subclinical Mastitis in Dairy Cows. Turkish Journal of Veterinary and Animal Sciences, 24(6):599-604.

Yalçin, C.,Yildiz, A.Ş., Sariözkan, S., Günlü, A., 2010. Producer Profiles, Production Characteristics and Mastitis Control Applications at Dairy Herds in Konya, Burdur and Kırklareli Provinces, Turkey. Ankara Üniversitesi Veteriner Fakültesi Dergisi, 57 (1):43-48. 